Взаимосвязь метаболитов обмена веществ и репродуктивных функций у коров

\section{The correlation of the metabolites metabolism and reproductive function in cows}

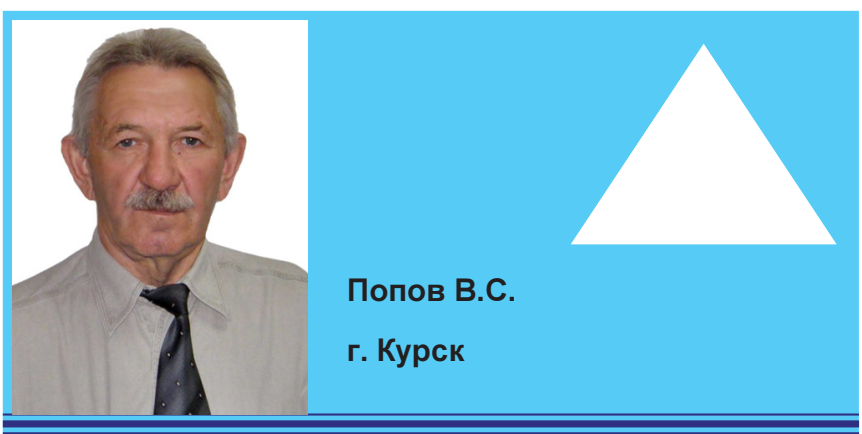

DOI 10.30917/ATT-VK-1814-9588-2018-4-2

УДК 619:618:612.015.3:636.2

Ключевые слова: метаболизм; биологически активная добавка; воспроизводительная способность; сервиспериод.

Key words: metabolism; biologically active additive; reproductive ability; service-period.

Резюме. В исследованиях установлено, что у коров в последний месяц стельности наблюдается напряженность обменных реакций, снижение иммунологической реактивности, сопротивляемости организма, что отрицательно влияет на отёл и течение послеотельного периода. Поэтому, кроме полноценного кормления, правильного ухода и содержания коров в сухостойный период, необходимо применение биологически активных кормовых добавок, которые активизируют обмен веществ, способствовали бы повышению и стабилизации защитных сил организма, с оптимизацией стадий отела и последующей субинволюцией матки, улучшением воспроизводительной фрнкции организма Уровень и направленность метаболитов обмена веществ имеют прямую взаимосвязь с воспроизводительной способностью животных и обусловлены интенсивным течением процессов обмена веществ в клетках, органах и тканях за счет адекватного поступления питательных веществ с кормом. Установлено, что напряженность фризиологических обменных реакций не в полной мере обеспечивалась количеством поступающих питательных веществ с кормом.

Следует предположить, что напряженность физиологических обменных реакций не в полной мере обеспечивалась количеством поступающих питательных веществ с кормом. Тем не менее, содержание общего белка в сыворотке крови находится в пределах физиологической нормы, вместе с тем наблюдается снижение этого показателя на 9,9\% с приближением отела. Следует отметить увеличение мочевой кислоты в крови в контрольной группе животных в пределах 11,4 \%, билирубина общего и билирубина прямо- го в пределах 4,2-86,7 \%, что свидетельствует о наличии мочеполовой патологии и ухудшении физиологического состояния организма. Вместе с тем, установлено повышенное содержание щелочного резерва крови от фризиологической нормы, что отрицательно влияет на кислотно-щелочной баланс организма глубокостельных животных. Таким образом, проведенные исследования подтверждают факт наличия у сухостойных коров иммунодефицита метаболической этиологии. Это явилось причиной задержания последов в послеродовом периоде у коров, сопутствующими эндометритами, несвоевременным приходом в охоту, увеличением сервис периода, снижением экономической эффективности производства молока.

Summary. In researches it is established that at cows in the last month of pregnancy tension of exchange reactions, decrease in immunologic reactivity, resistance of an organism is observed that negatively influences calving and during the postbody period. Therefore, in addition to full-fledged feeding, proper care and maintenance of cows in the dry period, it is necessary to use biologically active feed additives that activate the metabolism, would contribute to the increase and stabilization of the body's defenses, with optimization of the stages of calving and subsequent subinvolution of the uterus, improving the reproductive function of the body. The level and direction of metabolic metabolites have a direct relationship with the reproductive capacity of animals and due to the inten-sive flow of metabolic processes in cells, organs and tissues due to adequate supply of nutrients with feed. It was found that the intensity of physiological metabolic reactions was not fully provided by the number of incoming nutrients with feed.

It should be assumed that the intensity of physiological metabolic reactions is not fully provided by the amount of nutrients supplied with the feed. Nevertheless, the content of total protein in serum is within the physiological norm; however, there is a decrease of $9.9 \%$ with the approach of calving. It should be noted the increase of uric acid in the blood in the control group of animals in the range of $11.4 \%$, bilirubin total and bilirubin direct is between 4.2-86.7\%, which indicates the presence of genitourinary pathology and the deterioration of the physiological state of the body. At the same time, the increased content of alkaline reserve of blood from physiological norm is established that negatively influences acid-alkaline balance of an organism of deep-seated animals. Thus, the conducted researches confirm the fact of presence at dry cows of immunodeficiency of metabolic etiology. This was the reason for the detention of the placenta in the postpartum period in cows, the accompanying endometritis, the late joining the hunt, increase the service period, reduced economic efficiency of milk production.

Высокая продуктивность и воспроизводительная способность животных обусловлены интенсивным течением процессов обмена веществ в клетках, органах и тканях. Для обеспечения оптимального, физиологически обоснованного биосинтеза белков, энергии, роста, развития организма, производства молока, мяса и других продуктов животноводства высокого качества необходимо обязательное условие - в организм животных с рационом должны поступать все без исключения питательные вещества, участвующие в процессах обмена, в биологически требуемых количествах

\title{
Авторы / Authors
}

Попов В.С., доктор ветеринарных наук, главный научный сотрудник лаборатории "Биотехнологии животноводства", e-mail: viktor.stugen@yandex.ru

Воробьева Н.В., кандидат ветеринарных наук, старший научный сотрудник лаборатории "Биотехнологии животноводства"

ФГБНУ "Курский НИИ АПП", г. Курск

Popov V. S., Vorobyeva N.V. 
Таб̆лица 2. Динамика биохимических показателей крови коров, $(\mathrm{n}=10)$

\begin{tabular}{|c|c|c|}
\hline $\mathrm{n} / \mathrm{n}$ & Показатели & контроль/опыт \\
\hline 1 & Общий белок, г/л & $\frac{88,1 \pm 0,74}{79,4 \pm 0,27}$ \\
\hline 2 & Альбуммины, г/л & $\frac{41,44 \pm 0,66}{43,66 \pm 1,43}$ \\
\hline 3 & Глюкоза, ммоль/л & $\frac{1,96 \pm 0,57}{2,06 \pm 0,06}$ \\
\hline 4 & Резервная щелочность, Г\% & $\frac{627,2 \pm 2,17}{631,7 \pm 1,93}$ \\
\hline 5 & Холестерин, ммоль/л & $\frac{7,9 \pm 1,19}{2,19 \pm 0,19}$ \\
\hline 6 & ЛПВП, ммоль/л & $\begin{array}{l}0,61 \pm 0,04 \\
0,71 \pm 0,07\end{array}$ \\
\hline 7 & Мочевая кислота, ммоль/л & $\frac{508,4 \pm 22.84}{450,3 \pm 18,41}$ \\
\hline 8 & Триглишериды, ммоль/л & $\frac{0,39 \pm 0,12}{0,30 \pm 0,02}$ \\
\hline 9 & Креатинин, мкмоль/л & $\frac{98,4 \pm 7,31}{97,8 \pm 3,51}$ \\
\hline 10 & Каротин, мг/\% & $\frac{0,09 \pm 0,01}{0,07 \pm 1,21}$ \\
\hline 11 & Хлорилы, ммоль/л & $\frac{160,0 \pm 4,3}{159,15 \pm 3,7}$ \\
\hline 12 & Билирубин общий, мкмоль/л & $\frac{2,36 \pm 0,54}{4,41 \pm 1,82}$ \\
\hline 13 & Билирубин прямой, мкмоль/л & $\frac{1,92 \pm 0,64}{2,0 \pm 0,41}$ \\
\hline
\end{tabular}

Примечание: $\mathrm{P} \geq 0,05$

Таблица 3. Акушерские патологии в период опыта, $\mathrm{n}=10$

\begin{tabular}{|l|c|c|}
\hline \multirow{2}{*}{ Показатель } & \multicolumn{2}{|c|}{ Группа, гол. } \\
\cline { 2 - 3 } & 1-контрольная & 2-опытная \\
\hline Тяяелые отёлы & 9 & 1 \\
\hline Задержание последа & 10 & 7 \\
\hline Эндометрит & 5 & 0 \\
\hline
\end{tabular}

и соотношениях [2]. В последние дни перед отелом потребление корма снижается, а сразу после него потребность в энергии резко возрастает (до 25-30\%) и возникает так называемый "энергетический дефицит". При этом в первый месяц лактации происходит потеря живой массы в связи с дефицитом энергии, но в то же время чрезмерные запасы энергии в организме перед отёлом, приводит к атонии рубца, кетозу, снижению неспецифрического иммунитета и нарушению репродуктивной фрункции животных [1]

Ведущим фрактором является дефицит энергии, обусловленный составом кормовых средств и их питательностью в рационах коров сухостойного периода. При этом установлено, что у коров в последний месяц стельности наблюдается напряженность обменных реакций, снижение иммунологической реактивности, сопротивляемости организма, что отрицательно влияет на отёл и течение послеотельного периода. Поэтому, кроме полноценного кормления, правильного ухода и содержания коров в сухостойный период, необходимо применение биологически-активныхкормовыхдобавок, которые активизируют обмен веществ, способствовали бы повышению и стабилизации защитных сил организма, с оптимизацией стадий отела и последующей субинволюцией матки, улучшением воспроизводительной функции организма [6; 7; 5]. Следует отметить, что в основе этиопатогенеза акушерской патологи, в физиологические периоды репродукции у коров, одним из факторов является также состояние стрессовой дезадаптации, сопровождающееся снижением иммунологической резистентности в том числе за счет активизации условно-патогенной микрофлоры и вторичных иммунодесрици- тов метаболической этиологии. При этом акушерская патология в воспроизводительном цикле крупного рогатого скота может принимать массовый характер и сопровождается снижением воспроизводительной функции $[2,1,5,4]$.

Цель исследований. Определение биологической активности новой энергометаболической фрерментативноминеральной кормовой добавки в сухостойном периоде у коров.

\section{Материал и методы исследований}

Опыт проводили в учебном хозяйстве ФГБНУ ВО Курская ГСХА им. профессора И.И. Иванова. Объектом исследований являлись коровы сухостойного периода в возрасте от 3 до 9 лет. В период глубокой стельности, в количестве 65 голов из которых были отобраны две группы по 10 гол для проведения контрольных исследований. Условия содержания, кормления животных отвечали основным технологическим требованиям. Контрольная группа животных получала хозяйственный рацион. Во второй опытной группе использовали новую гранулированную кормовую добавку [3] из расчета 2,0 кг на 1 тонну комбикорма, содержащую 0,5 кг янтарной кислоты, 1,0 кг пробиотика целлобактерин (БАД на основе Bacillus subtilis), солодовые ростки до 1,0 тонны. Все обработанные животные находились под клиническим наблюдением. Гематологические и биохимические исследования крови проводили непосредственно перед отелом на автоматическом гематологическом анализаторе - Mindray BC-2800 с программным обеспечением Vet 2.3 для животных и биохимическим анализаторе - Stat Fax 1904.

\section{Результаты исследований и обсуждение}

Уровень и направленность метаболитов обмена веществ имеют прямую взаимосвязь с воспроизводительной способностью животных и обусловлены интенсивным течением процессов обмена веществ в клетках, органах и тканях за счет адекватного поступления питательных веществ с кормом. Рацион коров, сбалансированный на продуктивность 28-30 кг молока в сутки, состоял из сена многолетних трав - 2,0 кг, сенажа однолетних трав - 9,4 кг, силоса кукурузного - 15,5 кг, жома свекловичного сухого - 2,0 кг, патоки - 1,8 кг, соль - 0,15 кг и комбикорма на ячменно $(30 \%)$ пшеничной - (30\%) основе - 9,4 кг, содержащий отубей пшеничных - 10\%, шрот подсолнечниковый - 10\%, пивной дробины сухой - 15\%, дикальций фросфрат - $2 \%$, соль поваренная - $1 \%$ и премикс П60-3 - 1,0\%. Состав и питательная ценность биологически активной (БАД) кормовой добавки приведена в таблице 1.

Следует предположить, что напряженность фризиологических обменных реакций не в полной мере обеспечивалась количеством поступающих питательных веществ с кормом.

Так, содержание общего белка в сыворотке крови нахо-

Таблица 1. Состав и питательная ценность БАД, в 1 кг

\begin{tabular}{|c|c|c|c|c|c|}
\hline $\begin{array}{l}\text { Наименование } \\
\text { показателя }\end{array}$ & $\begin{array}{l}\text { Ед. } \\
\text { изм. }\end{array}$ & Кол-во & $\begin{array}{c}\text { Наименование } \\
\text { показателя }\end{array}$ & $\begin{array}{l}\text { Ед. } \\
\text { изм. }\end{array}$ & Кол-во \\
\hline ЭКЕ & & $1,05-1,06$ & Цинк & $\mathrm{M \Gamma}$ & $52-58$ \\
\hline Обменная энергия & МДж & $10,5-10,6$ & Марганец & MГ & $25,2-26,8$ \\
\hline Сухого вещества & $\Gamma$ & $90-93$ & Кобальт & $\mathrm{M \Gamma}$ & $0,05-0,1$ \\
\hline Сырой протеин & $\Gamma$ & $220-230$ & Йод & $\mathrm{M \Gamma}$ & $0,2-0,4$ \\
\hline Перев. протеин & $\Gamma$ & $192-210$ & Каротин & $\mathrm{M \Gamma}$ & $25-33$ \\
\hline Сырой жир & $\Gamma$ & $12-14$ & Витамин E & $\mathrm{M \Gamma}$ & $3,7-3,8$ \\
\hline БЭВ & $\Gamma$ & $485-495$ & Витамин $\mathrm{B}_{1}$ & МГ & 0,67 \\
\hline Кальций, & $\Gamma$ & $1,6-1,8$ & Витамин $\mathrm{B}_{2}$ & МГ & 0,51 \\
\hline Фосфор & $\Gamma$ & $8,3-8,5$ & Витамин $\mathrm{B}_{3}$ & $\mathrm{M \Gamma}$ & 1,88 \\
\hline Магний & $\Gamma$ & $1,7-1,8$ & Витамин $\mathrm{B}_{4}$ & МГ & 0,66 \\
\hline Cepa & $\Gamma$ & $7,9-8,2$ & Витамин $\mathrm{B}_{6}$ & МГ & 0,56 \\
\hline Янтарная кислота & $\Gamma$ & $0,5-0,7$ & Витамин РP & $\mathrm{M \Gamma}$ & 0,3 \\
\hline $\begin{array}{l}\text { Целлюлозолитич. микроорг. } \\
\text { (на основе Bacillus subtilis) }\end{array}$ & $\mathrm{KOE} / \Gamma$ & $\begin{array}{c}0,7- \\
0,9 \times 10 \sim 6\end{array}$ & Витамин C & $\mathrm{M \Gamma}$ & 6,24 \\
\hline
\end{tabular}

Примечание: микроэлементный и витаминный состав БАД, обеспечивается высоким их содержанием в солодовых ростках. 
дится в пределах физиологической нормы, вместе с тем наблюдается снижение этого показателя на 9,9\% с приближением отела. Уменьшение концентрации общего белка в сыворотке крови свидетельствует о его использовании в качестве пластического материала для тканей развивающегося плода и синтеза молозивных иммуноглобулинов. Альбуминовая фрракция белка в пределах физиологической нормы, что свидетельствует о достаточной обеспеченности рациона протеином, тем не менее, установлено увеличение в опытной группе на 5,4\%. Обращает внимание фракт очень низкого содержания глюкозы в крови, что свидетельствует о патологии печени и поджелудочной железы при достаточной сбалансированности рациона по легкоусвояемым углеводам и клетчатке. Следует отметить увеличение мочевой кислоты в крови в контрольной группе животных в пределах, 11,4\%, билирубина общего и билирубина прямого в пределах 4,2 - 86,7\% что, свидетельствует наличии мочеполовой патологии и ухудшении физиологического состояния организма. Вместе с тем, установлено повышенное содержание щелочного резерва крови от физиологической нормы, что отрицательно влияет на кислотно-щелочной баланс организма глубокостельных животных. Таким образом, проведенные исследования подтверждают фракт наличия у сухостойных коров иммунодефицита метаболической этиологии. Это явилось причиной задержания последов в послеродовом периоде у коров, сопутствующими эндометритами, несвоевременным приходом в охоту, увеличением сервис периода, снижением экономической эффрективности производства молока

Клинические наблюдения за степенью сложности отелов при проведении научно-хозяйственного опыта позволяют провести анализ по влиянию скармливания пробиотического БАД на воспроизводительные качества животных. На основе контроля осложнений были получены данные по количеству "тяжелых" отёлов, задержке последов, развитию эндометритов (табл. 3).

Анализ данных позволяет отметить, что помощь при отелах оказывалась во всех группах животных вследствие крупноплодности приплода и пониженной резистентности организма. Задержание последа отмечено в обеих группах животных. Эндометрит пролонгирует сервис-период у коров, что приводит к снижению показателя выхода телят. Анализ полученных данных показал, что эта патология была отмечена у животных 1-ой контрольной группы, тогда как у животных 2-ой опытной группы случаев эндометритов не установлено. Одним из самых ведущих показателей воспроизводства животных является длительность сервиспериода. В норме это показатель должен составлять 60-70 суток. В исследованиях установлено, что оплодотворение коров после первого осеменения было высоким в обеих группах (табл. 4), при этом, индекс осеменения у коров 2-й опытной группы был в итоге ниже контроля на $5,31 \%$, а сервис-период короче на 18 суток.

\section{Заключение}

Ведущим фактором является дефицит энергии, обусловленный составом и питательностью кормовых средств в рационах коров сухостойного периода. При этом установлено, что у коров в последний месяц стельности наблюдается напряженность обменных реакций, снижение иммунологической реактивности, сопротивляемости организма, что отрицательно влияет на отёл и течение послеотельного периода. Поэтому, кроме полноценного кормления, правильного ухода и содержания коров в сухостойный период, необходимо применение биологически-активных кормовых добавок, которые активизируют обмен веществ, способствовали бы повышению и стабилизации защитных сил организма, с оптимизацией стадий отела и последующей субинволюцией матки, улучшением воспроизводительной функции организма. В исследованиях установлено, что применение новой энергометаболической фрерментативно-минеральной кормовой добавки, активизировало обмен веществ в опытной группе животных. Вместе с тем имеются предположение о развитии скрытых патологий печени и мочеполовой системы, что подтверждается повышенным содержанием щелочного резерва крови, мочевой кислоты и билирубина. При этом установлены акушерские патологии после отела. Тем не менее, показатели воспроизводительной способности животных в опытной группе имеют положительную тенденцию к улучшению. Таким образом, определение эфффективности применения новой кормовой добавки к рационам сухостойных коров требует дальнейшего изучения.

\section{Литература}

1. Борознов С.Л., Мацинович А.А. Анализ причин выбытия и решение проблемы сохранности высокопродуктивных коров // Ученые записки УО. ВГАВМ. - Том. 42. - вып. В. 1.- часть 1. 2006. С.142-144. 2. Молочная продуктивность и показатели воспроизводительной способности коров в зависимости от отдельных факторов / Д.А Абылкасымов, Л.В. Ионова, Н.П. Сударев. П.С. Камынин // Молочное и мясное скотоводство. 2014. № 1. С. 9-11.

3. Попов В.С., Воробьева Н.В., Ульянов В.Б. Энергометаболическая кормовая добавка для стимуляции иммунометаболических процессов у коров в предродовой и послеродовой периоды: пат. 2650405 Рос. Федерации. № 2017117977; заявл. 23.05.17; опубл. 11.04 .18 , Бюл. № $11.7 \mathrm{c}$

4. Способ коррекции воспроизводительной функции у коров: пат. 2634055 Рос. Федерация. № 2016102018/ В.С. Попов, Н.В. Самбуров, Н.В. Воробьева, Ерыженская Н.Ф., Талдыкина А.А., Футыш О.Я.; заявл. 21.01.16; опубл. 23.10.17, Бюл. № 30. 6 с.

5. Способ коррекции иммунобиохимического статуса у коров в предродовом и послеродовом периодах: пат. 2475240 Рос. Федерации. № 2011104971/15/Ерыженская Н.Ф., Попов В.С., Воробьева Н.В., Щепихин С.Ю. ; заявл. 10.02.11 ; опубл. 20.02.2013, Бюл. № 5 . $6 \mathrm{c}$.

6. Усков Г.Е., Цопанова А.В., Лещук Т.Л. Воспроизводство стада важный элемент эффективности молочного скотоводства // Главный зоотехник. 2015. № 11-12. С. 9-14.

7. Энергометаболическое средство для глубокостельных и отелив. Эихся коров /А А. Евглевский, И И Михайпова О.Н Михайлова, В.Ю. Тарасов. Е.П. Евглевская // Ветеринария. 2016. № 9. С.13-16.

Таб̆лица 4. Показатели воспроизводительной способоности животных

\begin{tabular}{|l|c|c|c|c|}
\hline \multirow{2}{*}{ Показатель } & \multicolumn{2}{|c|}{ Контрольная } & \multicolumn{2}{|c|}{ Опытная } \\
\cline { 2 - 5 } & $\mathrm{M} \pm \mathrm{m}$ & $\mathrm{C} \%$ & $\mathrm{M} \pm \mathrm{m}$ & $\mathrm{C} \%$ \\
\hline Количество коров, гол & 10 & & 10 & \\
\hline Сухостойный период, суток & $67,89 \pm 1,66$ & 10,84 & $65,67 \pm 0,99$ & 6,59 \\
\hline $\begin{array}{l}\text { Период от начала введения } \\
\text { добавки до отела, суток }\end{array}$ & $10,75 \pm 1,14$ & 46,04 & $10,75 \pm 0,96$ & 53,70 \\
\hline Продолжительность стельности, суток & $278,89 \pm 1,66$ & 2,60 & $277,78 \pm 0,96$ & 1,50 \\
\hline Выделение последа, ч & $7,22 \pm 0,69$ & 36,75 & $5,44 \pm 0,35 *$ & 23,42 \\
\hline Индекс осеменения & $1,89 \pm 0,18$ & 41,39 & $1,22 \pm 0,10^{*}$ & 36,08 \\
\hline Восстановительный период, суток & $51,89 \pm 2,57$ & 24,05 & $43,00 \pm 3,18^{*}$ & $32 / 20$ \\
\hline Сервис-период, суток & $69,67 \pm 4,34$ & 26,77 & $51,44 \pm 4,37^{*}$ & $37,78 \mathrm{I}$ \\
\hline
\end{tabular}

Примечание: $\mathrm{P} \geq 0,05$ 